Olga Komirna,

$\mathrm{PhD}$ in Economics, Associate Professor Kyiv National University of Trade and Economics, 19, Kyoto str., Kyiv, 02156, Ukraine,

ORCID: 0000-0001-8842-1624

ResearcherID: O-5274-2016

Viktoriia Miniailo,

$\mathrm{PhD}$ in Economics

Kyiv National University of Trade and Economics, 19, Kyoto str., Kyiv, 02156, Ukraine, ORCID: 0000-0001-5867-7135

ResearcherID: A-7672-2019

Nezhyva Mariia,

$\mathrm{PhD}$ in Economics

Kyiv National University of Trade and Economics, 19, Kyoto str., Kyiv, 02156, Ukraine, ORCID: 0000-0002-3008-5338

ResearcherID: H-9408-2018

\title{
ACCOUNTING AND AUDIT OF THE EXPENDITURE OF OPERATING ACTIVITY OF ENTERPRISES OF THE RESTAURANT BUSINESS
}

The article investigates the expenditure of operating activities of enterprises of the restaurant business, specifies the features of their occurrence, methods of accounting for costs. The peculiarities of accounting of expenses of the enterprises of the restaurant economy on the basis of production method are revealed. Objects and stages of audit of expenses of operating activity of the restaurants are determined.

Keywords: restaurant business, accounting, audit, expenses.

Relevance of the research topic. Increased competition in the restaurant services market necessitates a constant improvement in the quality of products and services provided. It is important to create favorable conditions for intensifying the development of the restaurant industry in accordance with international quality standards of its transformation into a highly profitable competitive sphere, which accelerates the socio-economic development of entrepreneurship. The specific nature of the restaurant industry requires adequate control over the efficient and effective management of the restaurant industry, taking into account changes in the external and internal market environment. 
Formulation of the problem. The use of conservative forms of management, the orientation of the accounting system solely for the production and sale of its own products, accounting for unnecessary costs and writing off excess costs for products, lack of internal control of the production process and the provision of services causes problems in managing the business activities of restaurants. Therefore, for today it is important to develop applied recommendations on the organization and methodology of accounting and audit of expenditure to improve the efficiency and effectiveness of the restaurant industry, determine the prospects for its development in accordance with the chosen strategy.

Analysis of recent research and publications. Some theoretical, methodological and practical principles of accounting and audit of the expenditure of enterprises of restaurant business are studied in their works by such scientists as: L. Yancheva [8], O. Chumak, I. Andriushchenko [1], O. Hrytsenko [2], T. Kopotiienko [3], A. Yanchev, D. Shekhovtsova [7], Ya. Volkovska [6] and others. Recognizing the significant contribution of scientists, it is necessary to point out the presence of unresolved questions of scientific and applied nature in the part: improvement of internal reporting on accounting of operating expenses of the enterprises of the restaurant industry; improvement of analytical capabilities of factual information on accounting of expenses of the enterprises of the restaurant industry; organization of internal audit of the expenditure; control over the accounting of expenses; identifying ways to increase cost effectiveness.

Setting objectives. The purpose of this article is to evaluate the theoretical and practical principles of accounting and audit of the expenditure of operating activity of enterprises of the restaurant business and to provide recommendations for their improvement.

Presenting main material. Investigations of the essence of expenditure of operating activity of the enterprises of the restaurant economy were carried out in their scientific work O. Chumak and I. Andriushchenko [1], who under the expenses of the operating activity of the enterprises of the restaurant economy, realized the «cost of production financial results».

Features of activity of the enterprises of the restaurant economy influence the order of occurrence of expenses of operational activity of the enterprises of the restaurant economy. Characteristic for the enterprises of this industry is a considerable volume of transport and procurement costs, costs for delivery of products of own production to clients, etc. Also, the costs of entertaining and servicing can be attributed to the peculiarities of expenses incurred by the restaurants (Fig. 1). 


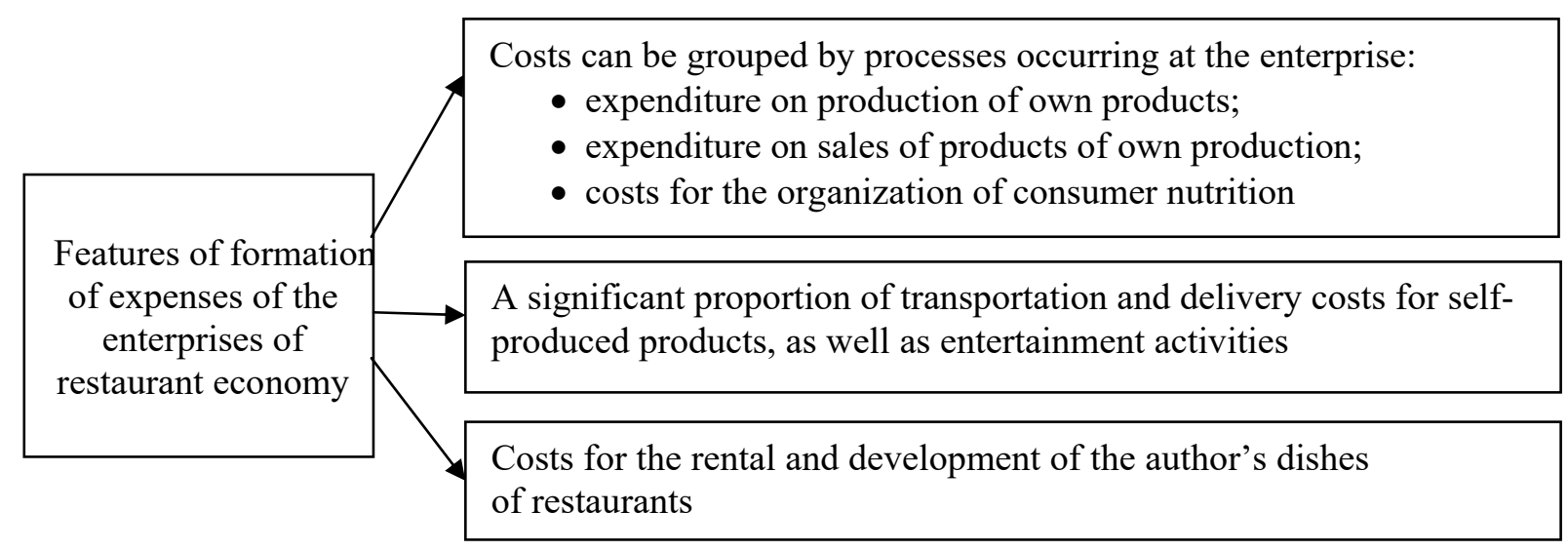

Fig. 1. Peculiarities of expenses arising from operating activities of restaurant business enterprises

Source: developed by the authors based on [8]

As can be seen from Fig. 1, the peculiarities of formation of costs of restaurant business enterprises are their division depending on the processes into: production costs, sales and consumption organization expenses. This feature is not characteristic of enterprises of other branches of national economy. According to the results of researches it is established that the enterprises of restaurant business can use both trade and production approach to reflect the expenses of operating activities in accounting (Fig. 2).

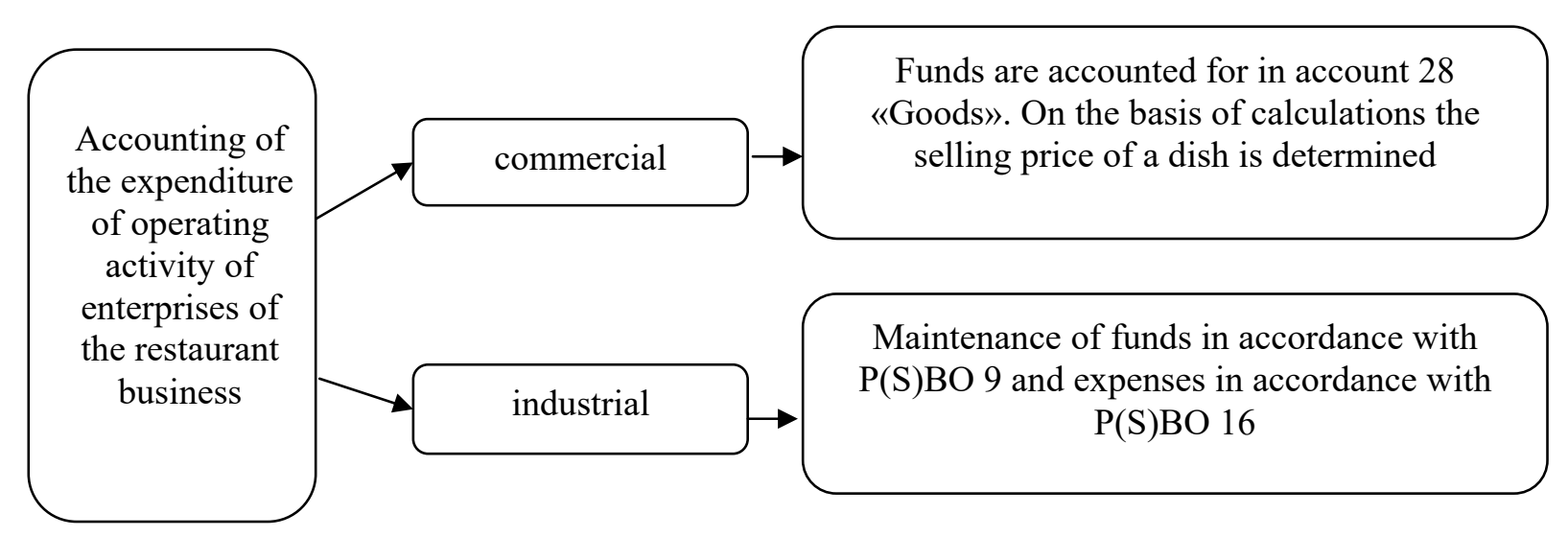

Fig. 2. Methods of accounting of expenses of operating activity of the enterprises of restaurant economy

Source: developed by the authors based on $[4,5]$ 
The results of the practical activity of the restaurant industry enterprises indicate that these enterprises mainly use the trade approach. Most cafes and restaurants keep records of raw materials, semi-finished products in warehouses and make subaccounts for 281 «Goods in stock» at sale prices.

In turn, the process of transferring raw materials to the kitchen is reflected by the following correspondence of the invoices Debit 282 «Goods in trading» Credit 281 «Goods in stock». According to this approach, the enterprises of the restaurant industry do not calculate the cost of the finished product, and therefore the account 23 «Production» is not used. Subaccount 902 «Cost of goods sold» generalizes information about the cost of goods sold and production of own production.

Account 92 «Administrative expenses» reflects the general economic expenses associated with the management and maintenance of the enterprise as a whole. Account 93 «Expenses of sales» reflects the costs associated with the sale (realization, organization of consumption, sale) of products (goods, works, services). On the same account, restaurant businesses also reflect costs directly related to the production of their own products (payroll to production workers; accrual on social measures depreciation of fixed assets, directly to production).

As Hrytsenko O. M. [2] indicate «... this approach is economically incorrect because major production costs cannot be defined as sales or other operating activities». The author considers that this procedure for displaying direct costs is incorrect, since in this case the accounting records are not kept through the account 23 «Production», which does not correspond to its economic content and the nature of direct costs as an element of production cost.

We agree with the opinion of the author, who proposes to use the production method in accounting for the costs of operating activities, and to reflect the cost of raw materials used for production of own production in the account 23 «Production» at the actual cost in terms of cost objects. Under the object of expenditures of the enterprises of the restaurant industry it is advisable to understand the output of finished products as a whole for the enterprise (Fig. 3) [2].

There fore, on account 23 «Production» it is expedient to reflect only the cost of raw materials used by the enterprise for the production of products of its own production. All other costs associated with the production process should be reflected in the account 91 «General production expenses» subaccount 911 «Kitchen costs», since these costs are related to production costs. In turn, the wages of employees engaged in the sale of products of their own production (waiters, other service personnel), as well as other costs (clothing, advertising costs, etc.) should be expensed to the expense of account 93 «Expenses of sales». 


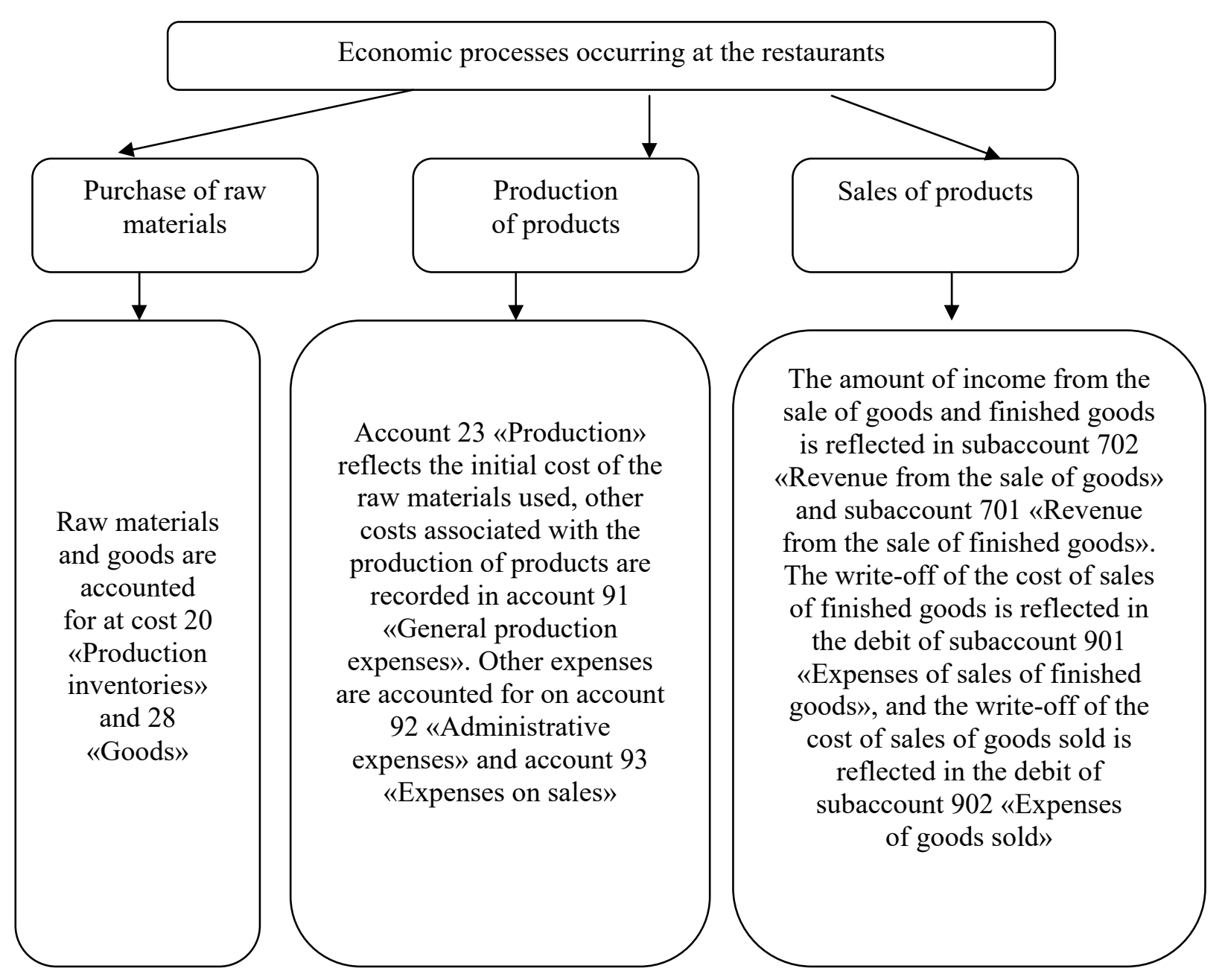

Fig. 3. Features of accounting of expenses of the enterprises of the restaurant economy on the basis of the production method

Source: developed by the authors based on [2]

In order to provide a more detailed account of these costs, it is advisable for the enterprises of the restaurant industry to maintain appropriate analytical accounts (Fig. 4), which introduction will allow to improve the informativeness of accounting data for the management system.

In general, in our opinion, the production method is more time consuming than the trade method, but it allows to calculate the actual cost of manufactured dishes and confectionery. The practical application of this method will allow users of accounting information to obtain more complete information, as well as the basic provisions of this method do not contradict standards. 


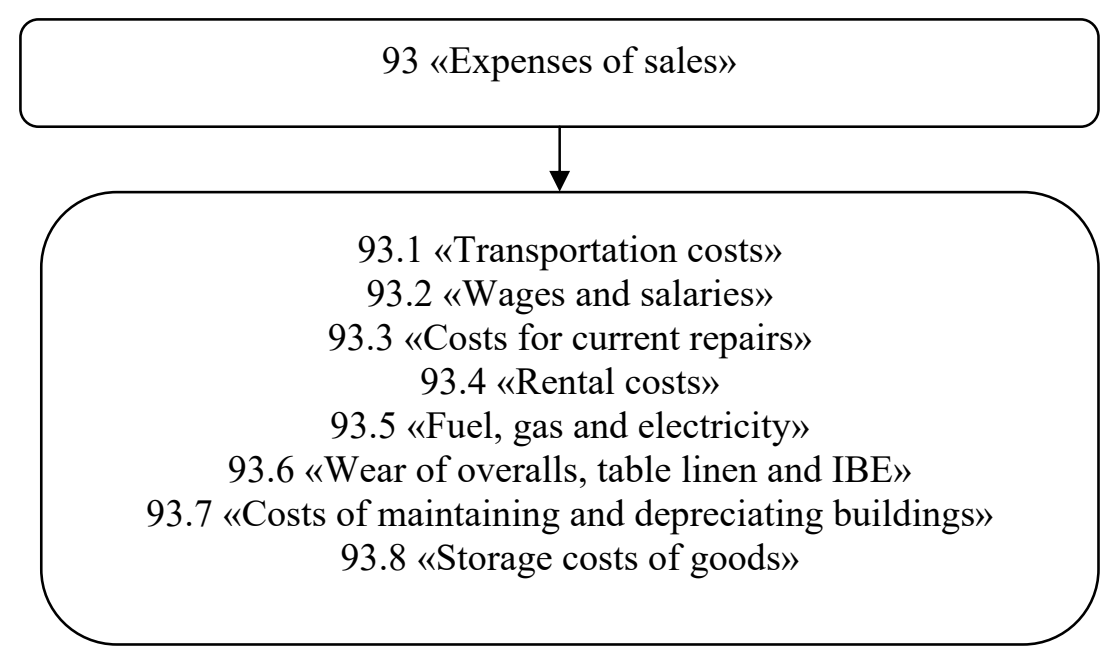

Fig. 4. Analytical accounts for subaccount 93 «Expenses of sales» of the enterprises of restaurant business

Source: developed by the authors

Carrying out an audit of the expenditure of operating activity of enterprises of the restaurant business involves determining the objects of audit:

- processes of purchase of raw materials and purchase goods, production of products, sale and service of visitors to the institution;

- operations with material, manpower, which led to the emergence of costs and their accounting;

- economic results of activity;

- cost of production of own production, administrative costs, sales costs;

- systems of cost management, management accounting, internal control.

Assessing the peculiarities of the activities and formation of expenses of operating activity by the restaurants, the following method of audit of the expenditure of operating activity can be proposed (Fig. 5).

An important task in audit is to solve costing problems, especially forecasting, by designing a future menu as a basis for further costs and then monitoring their implementation. In this case, the most common violations are non-compliance with consumption of raw materials during cooking; manipulation of calculation cards in order to hide the real cost price of finished products, etc. 


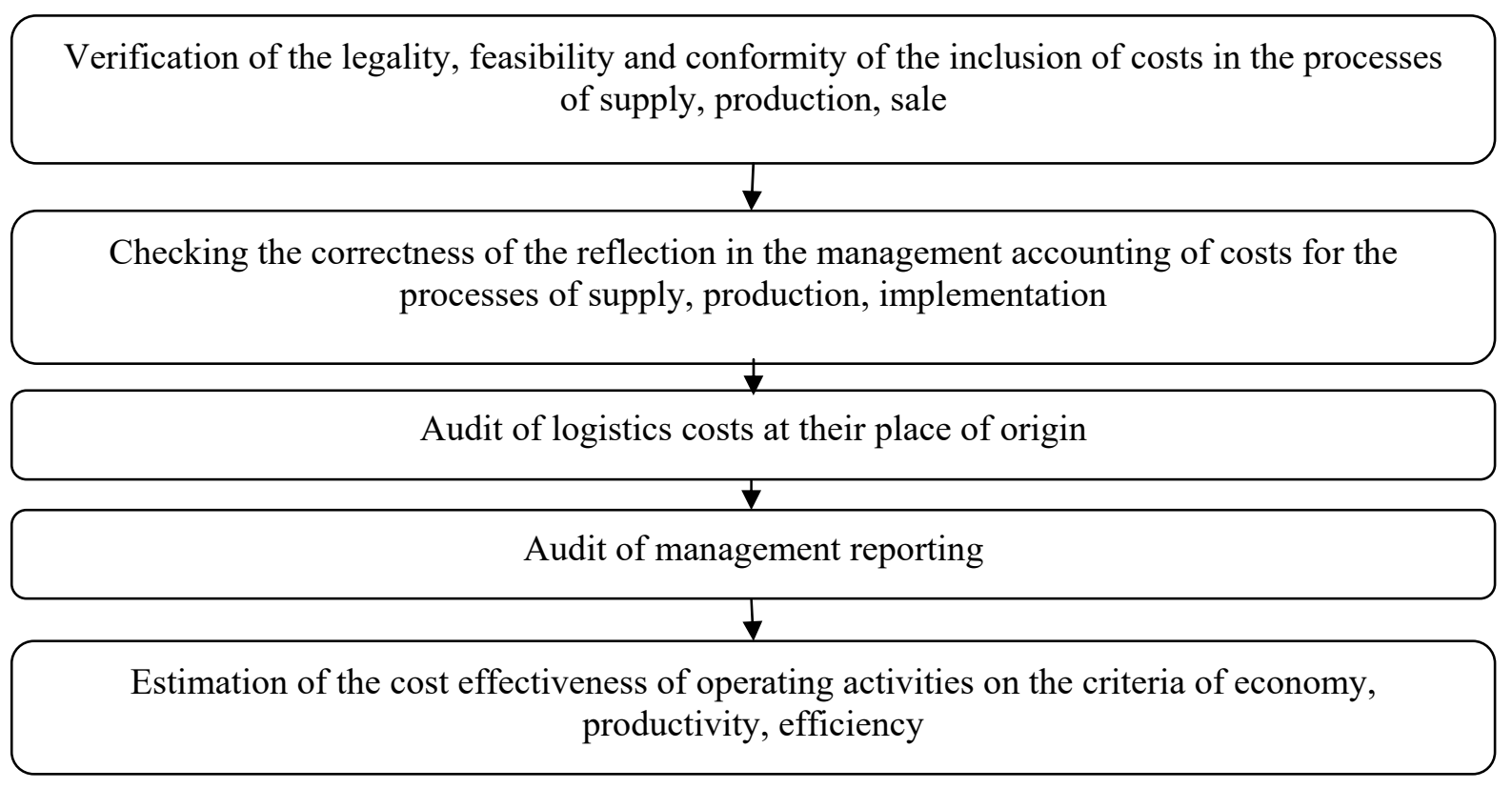

Fig. 5. Stages of audit of expenses of operating activity of the enterprises

Source: developed by the authors

$$
\text { of restaurant economy }
$$

In the process of checking the expenditure of operating activities, it is advisable to summarize the most common violations in the organization and accounting method. The main violations include:

- absence of a separate section in the accounting policy for accounting of the expenditure of operating activity of enterprises of the restaurant business;

- untimely formation of management reports on accounting of expenses;

- attribution of expenses not to the period in which they were actually incurred;

- incorrect allocation of transport and procurement costs and their inclusion in the original cost;

- inclusion in the operating expenses of unused stocks (products, raw materials, IBE);

- incorrect setting of raw material consumption rates according to the developed technological maps for the production of food and raw materials;

- incorrect write-off of deficiencies and losses within the limits of natural loss norms, etc.

A particular problem of cost audit is the definition and organization of the operation of the cost control system in the management system of the restaurant business. The presence of a «shadow» turnover causes the emergence of illegal cash proceeds. Therefore, the management of the restaurant business solves the issue of management as they arise, which practically makes it impossible to establish an effective audit system with its preventive function. 
It should be noted that the restaurant business entities form both financial and management reporting in which transactions are recorded for the occurrence of operating expenses. Business executives should be provided with timely and effective information on which to base sound management decisions.

To summarize information on expenditures in restaurant businesses, Journal 5A (Section III A «Activity expenditure «, Section III B « Expenditure by Elements») is assigned. The Journal's data is used to compile Form 2 of the financial statements («Income Statement»), which summarizes the actual costs of both the reporting and the previous periods with the breakdown by type of activity and economic elements.

This journal provides information for the formation of financial statements, at the same time, the management of the restaurant industry needs prompt and more detailed information on the costs arising from the processes occurring in the restaurant industry. To this end, we are offered one of the forms of management reporting, «Management Report on Expenses by Activity» (Table 1). It is advisable to formulate these reports on a regular basis, once a month.

Table 1

\section{Management Report on Expenses by Activity}

\begin{tabular}{|l|c|c|c|}
\hline $\begin{array}{c}\text { Costs of economic processes of } \\
\text { operating activities }\end{array}$ & $\begin{array}{c}\text { Expenses of the } \\
\text { previous period } \\
\text { (thousand UAH) }\end{array}$ & $\begin{array}{c}\text { Expenses of the } \\
\text { reporting period } \\
\text { (thousand UAH) }\end{array}$ & \% growth \\
\hline Delivery process & 101,1 & 156,3 & 54,5 \\
\hline Production process & 2767,8 & 2989,1 & 7,9 \\
\hline The implementation process & 405 & 467,8 & 15,5 \\
\hline Management process & 230,4 & 345,6 & 50 \\
\hline Together & 3504,3 & 3958,8 & 12,9 \\
\hline
\end{tabular}

Source: developed by the authors

This report will provide the necessary information for the analysis and control of costs in the management system and will provide an opportunity to evaluate the efficiency of the use of material, financial and labor resources for each process of operating of the enterprise.

Conclusion. Thus, the researches made it possible to establish that the existing practice of accounting of expenses contradicts the norms of the Instruction for the application of the Plan of Accounts, $\mathrm{P}(\mathrm{S}) \mathrm{BO} 9$ «Funds» and $\mathrm{P}(\mathrm{S}) \mathrm{BO} 16$ «Expenses». In this connection, the article proposes ways to optimize the accounting of the expenditure of operating activity of enterprises of the restaurant business. In order to improve accounting, recommendations have been made to improve internal reporting that will improve the information base provided by accounting for audit purposes. 


\section{REFERENCES}

1. Chumak, O. V., Andriushchenko, I. S. (2016). Cost management in the information and analytical system of the restaurant industry enterprises, $268 \mathrm{p}$.

2. Hrytsenko, O. M. (2014). «Improvement of the method of formation of production cost of production at the enterprises of the restaurant economy in the system of financial accounting», Scientific Bulletin of Kherson State University, Vol. 6, pp. 129-131.

3. Kopotiienko, T. Yu. (2014). «Internal audit in cost management of restaurant business», Bulletin of the National University «Lviv Polytechnic», Vol. 797, pp. 242-247.

4. Polozhennya (standart) bukhhalters'koho obliku 16 «Vytraty»: 31.12 .1999 № 318. Retrieved from: http://zakon2.rada.gov.ua/laws/show/z0751-99

5. Polozhennya (standart) bukhhalters'koho obliku 9 «Zapasy»: 20.10.1999 № 246. Retrieved from: http://zakon2.rada.gov.ua/ laws/show/z0751-99

6. Volkovska, Ya. V. (2018). Management accounting of operating expenses of the enterprises of the hotel and restaurant complex, $22 \mathrm{p}$.

7. Yanchev, A. V., Shekhovtsova, D. D. (2016). «Modern concept of organization of internal audit in the management of expenses of the enterprises of restaurant economy», Business Inform, Vol. 7, pp. 119-124.

8. Yancheva, L. M., Yanchev, A. V., Kyrylieva, L. O. (2017). Accounting and audit of expenditure of the enterprises of restaurant businesses: a managerial aspect, $262 \mathrm{p}$. 